\title{
Kepentingan Prelude Dalam Ibadah
}

\author{
Angelin Naomi Patty, Rohani Siahaan
}

\begin{abstract}
Abstrak
Tujuan dari penulisan karya ilmiah ini dilatar belakangi oleh pentingnya kesiapan jemaat dalam memasuki ibadah, karena ibadah merupakan perjumpaan antara jemaat dan Allah. Tetapi yang terjadi adalah kebanyakan di gereja sekarang ini, Worship Leader-lah yang berperan dalam mengajak jemaat melalui ajakan dalam berkata-kata untuk memasuki ibadah. Untuk itu, tujuan dari karya ilmiah ini adalah untuk menjelaskan pentingnya kesiapan jemaat dalam mempersiapkan diri sebelum memasuki ibadah melalui saat teduh yang diiringi dengan instrumen musik. Istilah musik untuk saat teduh dalam liturgi ibadah disebut prelude. Pembahasan ini menggunakan metode penelitian kepustakaan. Menjadi kesimpulan dari penulisan karya ilmiah ini adalah pertama, prelude merupakan musik pengantar untuk mempersiapkan jemaat masuk dalam ibadah dan prelude sangat mendukung dalam kesiapan jemaat untuk beribadah. Kedua, ibadah merupakan pertemuan antara Allah dan jemaat, sehingga sangat penting untuk mempersiapkan diri. Ketiga, prelude sangat penting dalam ibadah.
\end{abstract}

Kata-kata Kunci: Prelude, Ibadah, Jemaat, Musik.

\section{Pendahuluan}

\section{Latar Belakang Masalah}

Puji-pujian merupakan suatu unsur yang sangat penting dalam beribadah. Namun, ada unsur lain yang sama pentingnya, yaitu saat teduh. ${ }^{1}$ Gereja sekarang ini, dalam hal beribadah, kebanyakan tidak terlalu mementingkan adanya waktu untuk bersaat teduh. Sebenarnya saat teduh sangatlah penting untuk menjadi sarana yang menolong jemaat menghayati berkat Tuhan dan membimbing jemaat untuk bersaksi atas berkat Tuhan serta bersyukur untuk kebaikan Tuhan. Tetapi, kebanyakan yang terjadi adalah Worship Leader yang mengajak jemaat melalui ajakan dalam berkata-kata untuk memasuki suatu ibadah.

Ibadah merupakan pertemuan antara Allah dan jemaat ${ }^{2}$ sehingga diperlukan kesiapan yang sungguh-sungguh untuk siap masuk ke dalam hadirat Tuhan melalui penyembahan. Penyembahan harus perlu disiapkan. Dalam kebaktian, seperti pengkhotbah dan pemain musik harus mempersiapkan diri. Tetapi, persiapan yang paling penting dari semuanya adalah persiapan dari para penyembah secara pribadi, dan ini merupakan hal yang sering

\footnotetext{
${ }^{1}$ Wilfred J. Samuel, Kristen Kharismatik (Jakarta: Gunung Mulia, 2007), 61.

2 J. L. Ch. Abineno, Pokok-Pokok Penting Dari Iman Kristen (Jakarta: BPK Gunung Mulia, 2008),
} 217. 
diabaikan. ${ }^{3}$ Dalam Ibrani 10:22 mengatakan bahwa persiapan yang diharapkan Allah dari seorang penyembah ialah mempunyai hati yang tulus ikhlas serta keyakinan iman yang teguh. Ketika berbicara mengenai penyembahan, itu merupakan sesuatu yang harus diberikan kepada Allah. ${ }^{4}$ Penyembahan dimulai dengan memberikan pertama-tama diri, kemudian sikap, lalu apa yang dimiliki sehingga penyembahan menjadi cara hidup. ${ }^{5} \mathrm{Jadi}$, seorang penyembah yang benar harus mempunyai kesiapan yang baik dalam beribadah, dengan ketulusan, kesetiaan, kerendahan hati, kesucian, dan kesungguhan hati. ${ }^{6}$ Tanpa semua itu, penyembah tidak siap untuk memasuki hadirat Allah untuk menyembah. Tetapi, jika penyembah memiliki unsur-unsur tersebut, penyembah dapat mendekat dengan keberanian penuh dan Allah akan mendekat kepada penyembah. Itu merupakan janji ilahi, dan penyembah akan mencapai puncaknya yang paling mulia bila penyembah hidup dalam hadirat Allah, dalam cahaya kemuliaan-Nya, dan kehidupan dalam penyembahan. ${ }^{7}$

Istilah musik bagi saat teduh dalam sebuah liturgi ibadah disebut prelude. Prelude sangat berguna dalam mempersiapkan jemaat untuk masuk ke dalam hadirat Tuhan. Prelude dengan musik instrumen yang tenang dapat mendukung jemaat dalam mempersiapkan hati dan pikiran untuk masuk ke dalam hadirat Tuhan, ${ }^{8}$ karena pada dasarnya, keadaan yang tenang dapat membuat orang bisa fokus kepada apa yang akan dilakukan.

\section{Pokok Masalah}

Berdasarkan uraian latar belakang masalah yang telah diuraikan di atas, maka yang menjadi pokok masalah yang akan dikaji dalam karya ilmiah ini adalah: apakah prelude penting dalam ibadah?

\section{Tujuan Penelitian}

Adapun tujuan penulisan karya ilmiah ini adalah: untuk mengetahui pentingnya prelude dalam ibadah.

\section{Manfaat Penelitian}

Adapun manfaat penulisan yang diperoleh dari penulisan karya ilmiah ini adalah:

Pertama, menambah wawasan penulis dalam memahami pelayanan musik, secara khusus dalam prelude.

Kedua, memberi kesempatan kepada pembaca untuk mengetahui tentang pentingnya prelude dalam ibadah.

Ketiga, sebagai persyaratan untuk menyelesaikan pendidikan Stratum Satu (S1) pada Sekolah Tinggi Theologia Jaffray Makassar.

\footnotetext{
${ }^{3}$ John MacArthur Jr., Prioritas Utama Dalam Penyembahan (Bandung: Yayasan Kalam Hidup, 2001), 190.

4 John MacArthur, Jr., Prioritas Utama Dalam Penyembahan (Bandung: Yayasan Kalam Hidup, 2001), 26.

${ }^{5}$ Ibid., 6.

${ }^{6}$ Ibid., 190-191.

${ }^{7}$ Ibid., 193.

${ }^{8}$ Greg Scheer, The Art Of Worship (Malang: Literatur SAAT, 2015), 95.
} 


\section{Metode Penelitian}

Metode penelitian yang dipakai dalam penyusunan karya ilmiah ini adalah penelitian kepustakaan. Menggunakan buku-buku, kamus dan internet sebagai bahan untuk membantu penulis dalam menyelesaikan karya ilmiah ini yang berhubungan dengan karya ilmiah ini.

\section{Batasan Penulisan}

Dalam penulisan karya ilmiah ini, penulis membatasi penulisan hanya pada pentingnya prelude dalam ibadah.

\section{Kesimpulan}

Melalui penulisan karya ilmu musik ini, penulis menyimpulkan:

Pertama, prelude merupakan musik pengantar untuk mempersiapkan jemaat masuk ke dalam ibadah. Prelude, musik pengiring sangat mendukung jemaat dalam hal kesiapan untuk beribadah kepada Tuhan.

Kedua, ibadah adalah pertemuan antara Allah dan jemaat, di mana penyembah berfokus hanya untuk memuji dan memuliakan Tuhan. Ibadah membutuhkan persiapan yang baik, sehingga penyembah bisa menikmati hadirat Tuhan melalui ibadah.

Ketiga, prelude sangat menolong jemaat dalam mempersiapkan diri untuk masuk ke dalam hadirat Tuhan. Dengan sikap hati yang benar-benar tertuju hanya untuk Tuhan, dapat memberkati jemaat yang hadir dalam ibadah dan hadirat Tuhan dapat menjadi berkat bagi jemaat yang datang.

\section{Kepustakaan}

Abineno, J. L. Ch. Pokok-Pokok Penting Dari Iman Kristen. Jakarta: BPK Gunung Mulia, 2008.

Banoe, Pono. Pengetahuan Harmoni. Yogyakarta: Kanisius, 2007.

Christanday, Andreas. Pujian dan Penyembahan. Yogyakarta: Gloria Graffa, 2009.

Cornwall, Judson. Let Us Worship. Yogyakarta: ANDI, 2009.

Djohan. Terapi Musik. Yogyakarta: Galangpress, 2006. . Psikologi Musik. Yogyakarta: Buku Baik, 2005.

Handojo, Djohan E. The Fire Of Praise and Worship. Yogyakarta: ANDI, 2010. Henry, Matthew. Tafsiran Kitab Mazmur 101-150. Surabaya: Momentum, 2012. Husna, Aura. Kaya Dengan Bersyukur. Jakarta: Gramedia Pustaka Utama, 2013.

Lalu, Yosef. Yesus Kristus Pemberi Makna Hidup. Yogyakarta: Kanisius, 2012.

MacArthur Jr., John. Prioritas Utama Dalam Penyembahan. Bandung: Yayasan Kalam Hidup, 2001.

Mawene. Gereja Yang Bernyanyi. Yogyakarta: ANDI, 2007.

Mutak, Alfius Areng. "Disiplin Rohani Sebagai Praktek Ibadah Pribadi." Jurnal Theologi Aletheia 18, No.10 (Maret 2016):1-24. Diakses 27 Juli 2018. http://sttaletheia.ac.id/wp-content/uploads/2016/04/Jurnal-vol-18-no-10-Maret2016.pdf. 
Petersen, William J. \& Ardythe Petersen. Inspiring Stories About 600 Hymns And Praise Song. America: Tyndale, 2006.

Powell, Paul W. Tuhan, Mengapa Ini Harus Terjadi? Jakarta: BPK Gunung Mulia, 2000.

Rapar, Jan Hendrik. Pengantar Filsafat. Yogyakarta: Kanisius, 2010.

Redman, Matt. Menyembah Dalam Roh dan Kebenaran. Yogyakarta: ANDI, 2010.

Siahaan, Rohani. "Analisis Pengaruh Nyanyian Jemaat Terhadap Kualitas Ibadah Gereja Protestan Di Indonesia Bagian Barat (GPIB) Jemaat Bukit Zaitun Makassar.” Jurnal Jaffray Vol. 11, No. 2 (Oktober 2013):140-164. Diakses 22 Maret 2018. http://ojs.sttjaffray.ac.id/index.php/JJV71/article/download/82/pdf_65.

Samuel, Wilfred J. Kristen Kharismatik. Jakarta: Gunung Mulia, 2007.

Scheer, Greg. The Art of Worship. Malang: Literatur SAAT, 2015.

Segler, Franklin M., Randall Bradley. Christian Worship. Nashville, Tennessee: B\&H Publising Group, 2006.

Selvaraj, Sadhu Sundar. Seni Menyembah. Jakarta: Nafiri Gabriel, 1996.

Stewart, Ted C. Higher Level Worship. Yogyakarta: ANDI, 2008.

Tacoy, Selvester M. Identitas Gereja. Jakarta: Calvary Media, 2005.

Terry, Lindsay. I Could Sing of Your Love For Ever. Canada: Thomas Nelson, 2008. . The Sacrifice Of Praise. USA: Thomas Nelson, 2002.

Tippit, Sammy. Jumpa Tuhan Dalam Ibadah. Bandung: Lembaga Literatur Baptis, 1993.

Tison, Jermia Djadi. "Pengajaran Tentang Ibadah Berdasarkan Surat Ibrani 10:19-25 Dan Implementasinya Dalam Masa Kehidupan Orang Percaya Pada Masa Kini.” Jurnal Jaffray 11, No.1 (2013):37-66. Diakses 26 Juli 2018. http://ojs.sttjaffray.ac.id/index.php/JJV71/article/download/67/pdf_53.

Tong, Stephen. Yesus Kristuslah Juruselamat Dunia. Surabaya: Momentum, 2005.

Waesberghe, F. H. Smits Van. Estetika Musik. Yogyakarta: Thafa Media, 2016.

Warren dan Ruth Myers. Puji-Pujian Pintu Menuju Hadirat Tuhan. Bandung: Lembaga Literatur Baptis, 1990.

White, James F. Pengantar Ibadah Kristen. Jakarta: Gunung Mulia, 2009.

Widhyatama, Sila. Sejarah Musik dan Apresiasi Seni Di Asia. Jakarta: Balai Pustaka, 2013. Wijaya, Hengki. Analisis Data Kualitatif. Makassar: Sekolah Tinggi Theologia Jaffray, 2018.

Wijaya, Hengki (ed.). Metodologi Penelitian Pendidikan Teologi. Makassar: Sekolah Tinggi Theologia Jaffray, 2016.

Wongso, Peter. Soteriologi (Doktrin Keselamatan). Malang: Seminari Alkitab Asia Tenggara, 1998.

Young, Kim Woo. Yesuslah Jawaban. Jakarta: BPK Gunung Mulia, 2005. 